Article

\title{
Timing is Not Everything: Assessing the Efficacy of Pre- Versus Post-Harvest Herbicide Applications in Mitigating the Burgeoning Birch Phenomenon in Regenerating Hardwood Stands
}

\author{
Alejandro A. Royo ${ }^{1, *}$, Cornelia C. Pinchot ${ }^{2}$, John S. Stanovick ${ }^{3}$ and Susan L. Stout ${ }^{1}$ \\ 1 USDA Forest Service, Northern Research Station, 335 National Forge Road, P.O. Box 267, \\ Irvine, PA 16329, USA; sstoutfs@gmail.com \\ 2 USDA Forest Service, Northern Research Station, 359 Main Road, Delaware, OH 43015, USA; \\ corneliapinchot@fs.fed.us \\ 3 USDA Forest Service, Northern Research Station, 1549 Long Pond Road, Long Pond, PA 18334, USA; \\ jstanovick@fs.fed.us \\ * Correspondence: aroyo@fs.fed.us; Tel.: 814-563-1040
}

Received: 13 March 2019; Accepted: 3 April 2019; Published: 11 April 2019

\begin{abstract}
Sweet birch (Betula lenta L.) is aggressively recruiting in temperate forest understories of the eastern United States and often dominates the post-disturbance seedling community, diminishing diversity and hindering sustainable silviculture. The type and timing of silvicultural actions affect birch recruitment via their effects on seedling recruitment, survival, and growth. Here, we examine birch regeneration under two contrasting treatment sequences: pre- versus post-shelterwood harvest herbicide application (H-S vs. S-H) in combination with white-tailed deer (Odocoileus virginianus Zimmerman) browsing (fenced vs. unfenced) at 22 sites in northwestern Pennsylvania, USA. Additionally, we examine how treatments interact with additional site factors, including potential propagule sources and site productivity (i.e., integrated moisture index). We found the S-H sequence initially reduced birch density by $71 \%$ relative to the $\mathrm{H}-\mathrm{S}$ sequence; however, the magnitude of this reduction waned over five growing seasons. Furthermore, birch proliferated following the H-S sequence only where mature birch were present. Deer browsing reduced birch height by $29 \%$ relative to fenced areas protected from browsing; however, by the fifth growing season birch seedlings were over twice as tall as other hardwood species across all treatments. Finally, increasingly mesic sites enhanced birch height growth. In sum, although post-harvest herbicide (S-H) provides short-lived control over birch, land managers should also consider browse pressure, seed source, and site productivity, as these may enhance or diminish the efficacy of post-shelterwood herbicide sequence effects on birch.
\end{abstract}

Keywords: herbivory; succession; Allegheny; northern hardwoods

\section{Introduction}

Within the last two decades, sweet birch (Betula lenta L.; hereafter, birch) has emerged among the few species that consistently and abundantly recruit into mesophytic and northern hardwood forests of the eastern United States. Forest Inventory and Analysis (FIA) data show, for example, sweet birch sapling (2.5-12.5 cm diameter at breast height (DBH)) density increases of $11 \%$ from 2004 to 2014 in Pennsylvania and 24\% from 1993 to 2007 in New York [1,2]. This upsurge is remarkable given that, unlike other species increasing in forest understories (e.g., beech (Fagus grandifolia L.)), the relative abundance of birch in the canopy is disproportionately low compared to its abundance 
in forest understories [1]. The proliferation of birch is particularly pronounced following overstory disturbances (e.g., pests, wind, and forest harvests), leading to situations where birch overwhelmingly dominates the regeneration layer [3-7]. Thus, the burgeoning birch phenomenon poses a serious challenge to forest managers who strive to sustain forest diversity and values in the face of seedling demography trends that suggest future forests are becoming increasingly monodominant.

Birch increases in forest understories appear to be the 21st century analogue to the red maple (Acer rubrum L.) surge of the 20th century that has now stabilized or even declined in many regions [1,2,8]. Like red maple, birch may be considered a 'super-generalist' (sensu [9]) in that it possesses wide amplitude in key traits that confer recruitment, survival, and growth advantages under a variety of conditions, including recently disturbed stands. This versatility is, perhaps, most evident in its shade tolerance, which has been categorized as intolerant to intermediate [10,11], yet research demonstrates birch seedlings are able to survive and grow even under extremely low light levels (i.e., $<5 \%$ of full sun; $[12,13]$ ). The species' versatility in ecological attributes is not limited to shade tolerance. For example, birch is not hypothesized to be strongly recruitment limited, as mature trees are prolific and frequent seed producers with broad seed dispersal capabilities [10,14]. Dispersed seeds germinate best on exposed mineral soil, which often increases following harvesting; however, they also germinate readily in undisturbed sites $[15,16]$. Further, although birch seedlings are browsed by white-tailed deer (Odocoileus virginianus Zimmerman), the species is relatively insensitive to browsing [17] and can dominate forest understories even under moderately high deer populations [18,19]. Finally, it is also possible that birch benefits from changes in soil nutrient availability, including the nitrogen pulse that exists post-overstory disturbance, with enhanced establishment, particularly when light is not limiting [20-22].

In actively managed forests, the intensity and timing of forest harvesting, along with the additional silvicultural practices that often accompany cutting, have the potential to either promote or mitigate birch dominance. For example, the degree to which harvesting operations disturb soil, enhance nitrogen mineralization, and increase light may regulate birch recruitment success [23]. The timing of key silvicultural actions may also greatly affect birch establishment. Here, we focus on the regeneration dynamics that occur following two contrasting treatment timing sequences: pre- versus post-shelterwood harvest herbicide applications. Within the Allegheny hardwoods and northern hardwood forest types, the herbicide-shelterwood sequence was the recommended approach during the late 20th century in an effort to chemically control pre-existing and highly recalcitrant herbaceous competing vegetation either before or at the time of the shelterwood harvest [24-26]. Over the past two decades, however, managers have shifted to a shelterwood-herbicide sequence in an effort to limit dominance by woody species that establish aggressively post-harvest [27]. The rationale underlying this shift in practice is that fast-growing woody competitors that readily establish from the seed bank following a harvest are subsequently controlled by the broadcast herbicide application and further recruitment is limited relative to the initial post-disturbance pulse given the depletion in the seed bank [28]. Additionally, this approach is pragmatic, as unforeseen harvesting delays (e.g., weather, market volatility) may provide sufficient time for the re-establishment of interfering vegetation where pre-harvest herbicides were applied. Nevertheless, this approach may be of limited utility when the competitor is a species like birch, where seedling recruitment from seeds comes not from an on-site seed bank that may be depleted, but rather from a continuous source of wind-dispersed seeds.

In this study, we used data from nearly two dozen managed stands across multiple ownerships to examine how the application of the predominant even-aged regeneration prescription in the Allegheny hardwood forest type, the shelterwood seed cut and herbicide combination, influences birch establishment. If post-harvest conditions promote birch establishment and growth, then we predict the shelterwood-herbicide sequence will reduce birch seedling densities and height development relative to the herbicide-shelterwood sequence. Moreover, as birch recruitment and growth are known to be influenced by site productivity, browse pressure, and propagule supply, we further predict birch 
seedling densities and height will be greater in sites with increased soil nitrogen and moisture, greater light availability, low deer browsing, and where mature birch exist in the canopy.

\section{Methods}

\subsection{Study Area}

We conducted our study at 22 northern hardwood forest sites distributed throughout a $6500-\mathrm{km}^{2}$ area of northern Pennsylvania, USA. The chosen sites had a mean elevation of $605 \mathrm{~m}$, a humid, temperate climate with average daily temperatures of $9{ }^{\circ} \mathrm{C}$, and average annual precipitation of $1067 \mathrm{~mm}$ [29]. Fecal pellet surveys at these sites conducted between 2014-2016 found that deer densities averaged $7.04 \pm 0.48$ deer $/ \mathrm{km}^{2}$, levels which are moderate given historic trends in the region [30].

At all sites, managers conducted the initial cut (i.e., the preparatory cut) of a shelterwood sequence to reduce stand relative density (i.e., $<75 \%$ relative density) and applied broadcast herbicides (tank mix of glyphosate and sulfometuron methyl; [31]) to control interfering plant species and reinitiate seedling recruitment. Herbicide application was accomplished using mist-blowers mounted on skidders. Where reported, application rates varied from $1.8-3.8 \mathrm{~kg} / \mathrm{ha}$ of active ingredient for glyphosate and $0.14-0.21 \mathrm{~kg} / \mathrm{ha}$ of sulfometuron methyl. Twelve sites received a herbicide-shelterwood sequence $(\mathrm{H}-\mathrm{S})$ and ten received a shelterwood-herbicide sequence ( $\mathrm{S}-\mathrm{H}$; see Appendix A). Preparatory cuts in the H-S sequence occurred 0-2 years prior to vegetation monitoring, while herbicide applications in the S-H sequence sites occurred two years prior to vegetation monitoring. Within each site, we established two 0.42 -ha $(60 \times 70 \mathrm{~m})$ plots and randomly assigned one plot a deer exclosure (fence) treatment while the other served as an unfenced control. Exclosure construction was completed by September 2013, one year prior to vegetation monitoring.

Additionally, we calculated various other site variables for each plot. Site productivity was estimated using Iverson et al.'s [32] integrated moisture index (IMI). The IMI combines GIS-derived topographic and soil features of the landscape that govern moisture availability (i.e., direct solar radiation, slope position, curvature, and soil water holding capacity) into a single index of relative moisture and site productivity. We assessed nitrogen availability for each site using soil samples from the $\mathrm{A}, \mathrm{B}, \mathrm{O}$, and $\mathrm{E}$ horizons. Ammonium nitrogen $\left(\mathrm{NH}_{4}\right)$ and nitrate $\left(\mathrm{NO}_{3}\right)$ concentration estimates were converted to total nitrogen $(\mathrm{mg} / \mathrm{kg})$ using their molar ratios. Finally, we conducted post-harvest variable radius stem surveys using a 10-factor prism to determine whether mature, potentially seed-bearing, birch were present in the overstory of each plot and to calculate overstory relative density. Relative density is an estimate of overstory crowding that integrates both tree size and species identity and serves as our surrogate for light availability [33].

\subsection{Vegetation Surveys}

We surveyed tree seedling regeneration in the 2014, 2015, and 2017 growing seasons at each plot. Sampling occurred in 1- $\mathrm{m}^{2}$ circular subplots located at the nodes of a $10 \mathrm{~m} \times 10 \mathrm{~m}$ grid established within the central 0.2 ha $(40 \mathrm{~m} \times 50 \mathrm{~m})$ area of each plot. We recorded densities of established seedlings (i.e., not new germinants, $>5 \mathrm{~cm}$ in height) and the height of the tallest individual, by species. Due to limitations in personnel, we sampled the 15 odd-numbered subplots in 2014 and 2017 and all 30 subplots in 2015. Mean density $\left(\right.$ stems $/ \mathrm{m}^{2}$ ) and average height $(\mathrm{cm})$ were calculated for each site, plot, and year.

\subsection{Statistical Analyses}

We employed an analysis of covariance approach using generalized linear mixed models (PROC GLIMMIX; [34]) to examine the factors that predispose stands to high birch seedling and sapling dominance. To avoid model overfitting when testing multiple covariates, we followed Littell and colleagues' [35] guidelines, which recommend a sequential model-building approach in which the form 
of each covariate is evaluated independently prior to entering into a final model. This approach first investigated whether the slopes were equal across treatments (i.e., treatment $\times$ covariate interaction). If the interaction was deemed non-significant, we then examined whether a common slopes model (i.e., simple covariate) was appropriate. Alternatively, if slopes were unequal then treatment effects were tested at a minimum of three levels of the covariate. For our purposes, we chose the 10th percentile, the median, and the 90th percentile for each chosen covariate, when appropriate. Each potential covariate was tested against our two fixed silvicultural treatment effects: silvicultural sequence (H-S versus $\mathrm{S}-\mathrm{H})$ and deer browsing (ambient versus exclosure). Only significant covariates or treatment $\times$ covariate effects were included in a final model. The tested co-variables were as follows: birch seed source in the plot (binary: 0 versus 1), site productivity/moisture (continuous: IMI), canopy openness (continuous: relative density), and total nitrogen (continuous). One observation was removed from the input dataset for birch seedling densities, as it was identified as an outlier (i.e., large residual) that exerted high leverage (PROC ROBUSTREG; [34])

Response variables included both established birch seedling density (\# individuals $/ \mathrm{m}^{2}$ ) and birch seedling height $(\mathrm{cm})$. Additionally, to explore whether any possible reductions in birch density or height benefited the regeneration of other species, we examined silvicultural sequence and browsing effects on the average stem density and height of all co-occurring species of higher economic regional importance (i.e., desirable). Desirable species in our surveys included Acer rubrum L., A. saccharum Marshall, Fraxinus americana L., Liriodendron tulipifera L., Magnolia acuminata L., Prunus serotina Ehrh., and Quercus rubra L.

Birch density and height were analyzed using a repeated measures analysis of covariance randomized incomplete block factorial design. For both models, sequence, enclosure, year, and the associated interactions were fixed effects, and site was a random effect. Models on desirable species density and height were tested on 2017 data only. Therefore, we used a randomized incomplete factorial design with these two models. Sequence, enclosure, and the associated interaction were fixed effects in these models, and site was the random effect.

Seedling heights were modeled with a lognormal distribution with the identity link function, and average seedling densities were modelled with a gamma distribution using the log link function. Correlations between years were modelled using a spatial power covariance structure. We used the Kenward-Rogers denominator degrees of freedom adjustment method for each model. In addition, normality was statistically tested using the Shapiro-Wilk test, and homogeneity of variance was tested with Levene's test [36]. For significant treatment $\times$ year effects, we compared treatments within years using the SLICE option of the LSMEANS statement, and any treatment $\times$ covariate tests were accomplished using the LSMESTIMATE function with the AT = option for the three levels of the covariate. We used a critical value of $p=0.10$ as significant and employed a Bonferroni correction when examining multiple comparisons.

\section{Results}

Initial (2014) birch seedling densities were 71\% lower in areas treated with the S-H sequence relative to the $\mathrm{H}-\mathrm{S}$ sequence; however, seedling densities were statistically equivalent between treatments by 2015 and grew even more equitable by 2017 (sequence $\times$ year effect; Table 1; Figure 1). Within the H-S sequence areas, birch established at high densities only where residual birch existed in the overstory (Table 1; Figure 2). In fact, areas with the H-S sequence that lacked mature birch in the canopy had birch seedling densities comparable to S-H areas (Figure 2). Overall, deer browsing had no effect on birch seedling densities. Excluding browsers in the H-S treatment did result in seedling densities that were two- to three-fold greater than other treatments (exclosure $\times$ sequence effect; Table 1; Figure 3); however, these initially significant differences $(p<0.10)$ were non-significant following the adjustment for multiple comparisons. Site productivity (IMI) and relative density were identified as potential covariates in the exploratory model-building phase for birch density; however, neither was significant when entered into the full model. 
Table 1. Final generalized linear mixed model for established birch seedling densities. See Methods section for model specification.

\begin{tabular}{ccc}
\hline Effect & $\boldsymbol{F}$-Value & $\boldsymbol{p}$-Value \\
\hline Sequence & $F_{1,23.5}=0.01$ & 0.942 \\
Exclosure & $F_{1,21.4}=0.00$ & 1.000 \\
Exclosure $\times$ Sequence & $F_{1,21.4}=6.87$ & 0.016 \\
Year & $F_{2,69.2}=7.48$ & 0.001 \\
Sequence $\times$ Year & $F_{2,69.2}=7.97$ & 0.001 \\
Exclosure $\times$ Year & $F_{2,69.2}=0.30$ & 0.744 \\
Exclosure $\times$ Sequence $\times$ Year & $F_{2,69.2}=0.43$ & 0.651 \\
Sequence $\times$ Seed Source & $F_{2,29.1}=6.02$ & 0.006 \\
\hline
\end{tabular}

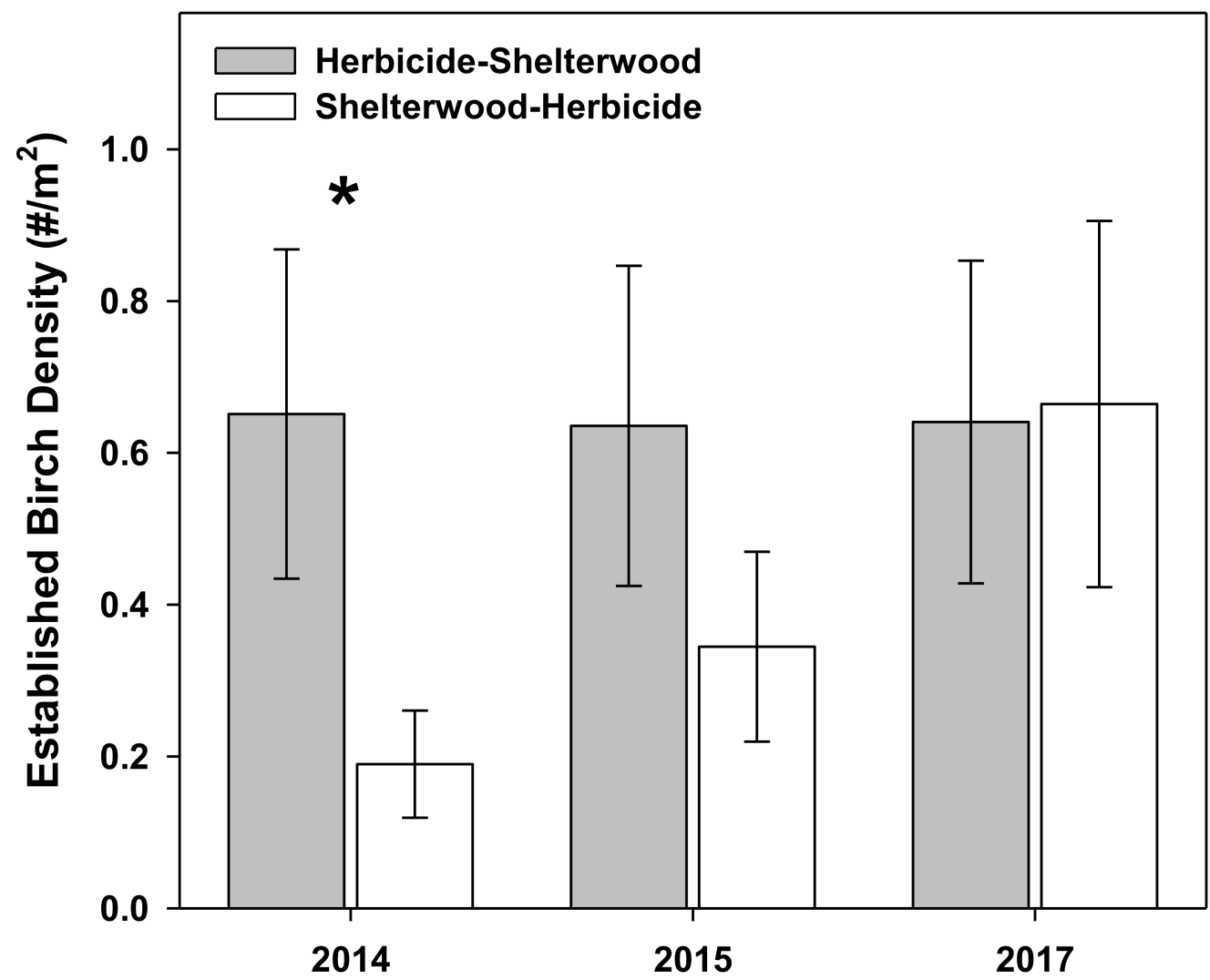

Figure 1. Effect of pre- versus post-shelterwood harvest herbicide application on birch seedling densities (\# individuals $>5 \mathrm{~cm} / \mathrm{m}^{2}$ ) over time. Asterisks denote significant Bonferroni-corrected difference between treatments within a census period. 


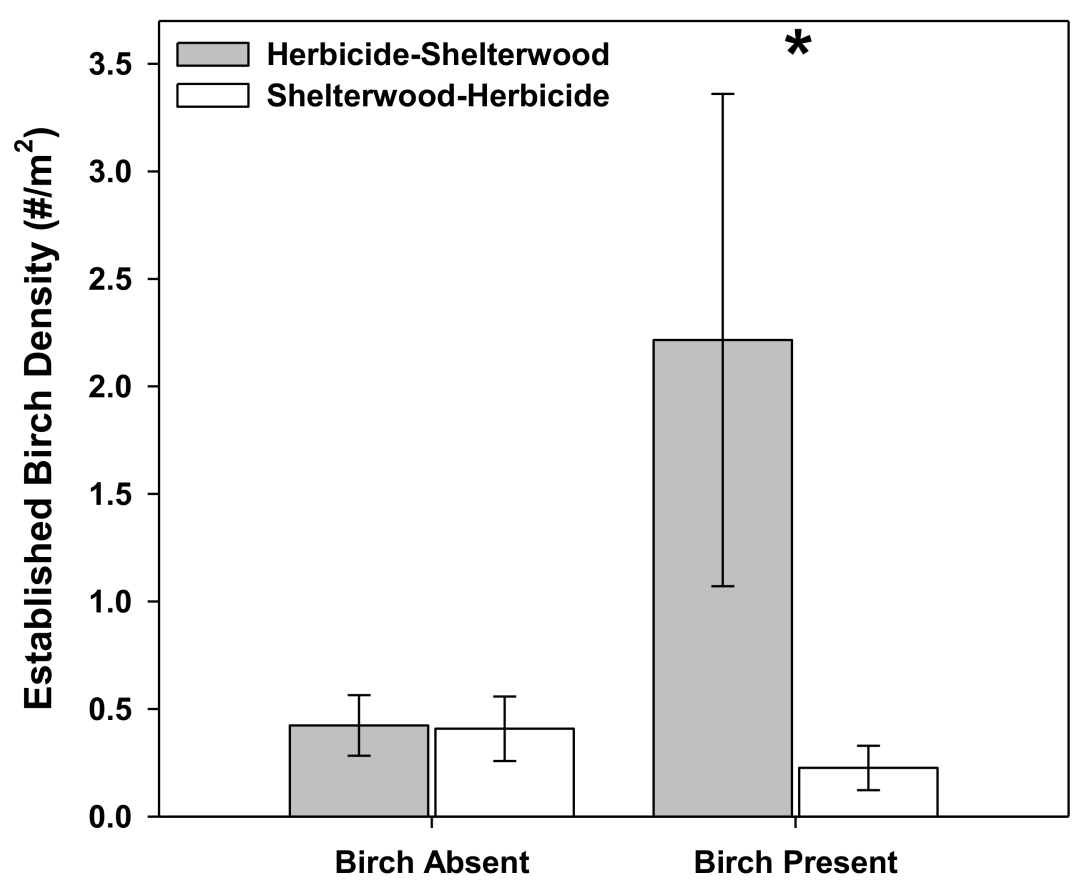

Figure 2. Effect of pre- versus post-shelterwood harvest herbicide application and presence of residual birch trees in stand (none/some) on birch seedling densities (\# individuals $>5 \mathrm{~cm} / \mathrm{m}^{2}$ ) over time. Asterisks denotes a significant Bonferroni-corrected difference between treatments at either level of the birch presence covariate.

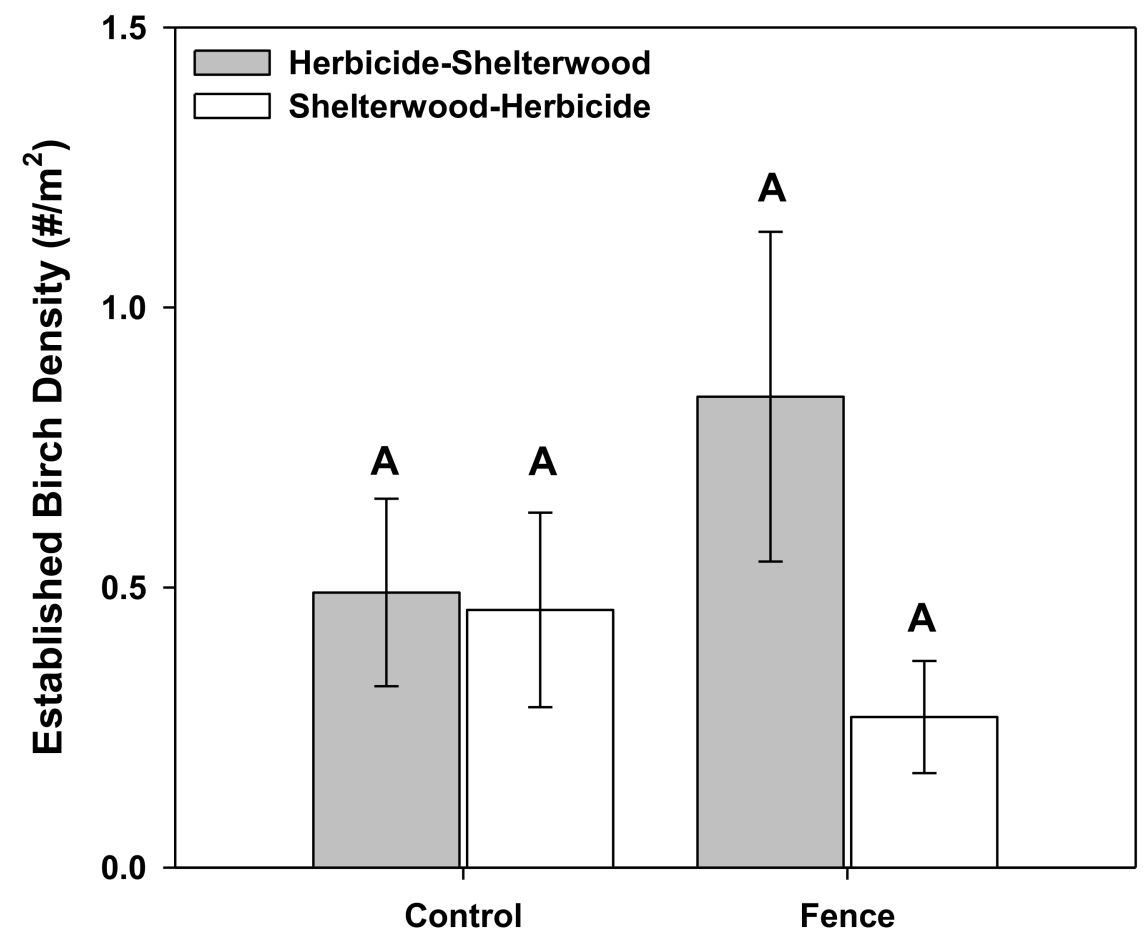

Figure 3. Effect of pre- versus post-shelterwood harvest herbicide application in combination with white-tailed deer browsing on birch seedling densities (\# individuals $>5 \mathrm{~cm} / \mathrm{m}^{2}$ ). Letters denote Bonferroni-corrected differences among all treatment combinations.

Birch seedlings grew over time, attaining an average height of $80.1 \pm 11.9 \mathrm{~cm}$ by 2017, regardless of silvicultural treatment sequences or browsing pressure (Table 2). Deer browsing reduced birch seedling heights by $29 \%$ when averaged across all sample periods (Table 2, Figure 4). By 2017, birch seedlings 
were $61.7 \pm 11.3$ and $103.92 \pm 19.5 \mathrm{~cm}$ in control and fenced areas, respectively. Birch seedlings attained larger heights as site productivity (IMI) increased, irrespective of treatments, but the relationship had high variability $\left(F_{1,105}=13.27 ; R^{2}=0.11\right.$; Table 2 ; Figure 5$)$. No other potential covariates were identified in the model-building phase as important factors driving the birch height response.

Table 2. Final generalized linear mixed model for established birch seedling height. The model-building phase did not identify any of the site-level covariates as sufficiently important for inclusion in final model. IMI: integrated moisture index.

\begin{tabular}{ccc}
\hline Effect & $\boldsymbol{F}$-Value & $\boldsymbol{p}$-Value \\
\hline Sequence & $F_{1,19.3}=1.46$ & 0.241 \\
Exclosure & $F_{1,49.2}=6.62$ & 0.013 \\
Exclosure $\times$ Sequence & $F_{1,49.2}=0.00$ & 0.999 \\
Year & $F_{2,55.0}=46.53$ & $<0001$ \\
Sequence $\times$ Year & $F_{2,55.0}=0.42$ & 0.658 \\
Exclosure $\times$ Year & $F_{2,56.1}=0.55$ & 0.579 \\
Exclosure $\times$ Sequence $\times$ Year & $F_{2,56.1}=0.44$ & 0.646 \\
Mean IMI & $F_{1,19.2}=6.25$ & 0.022 \\
\hline
\end{tabular}

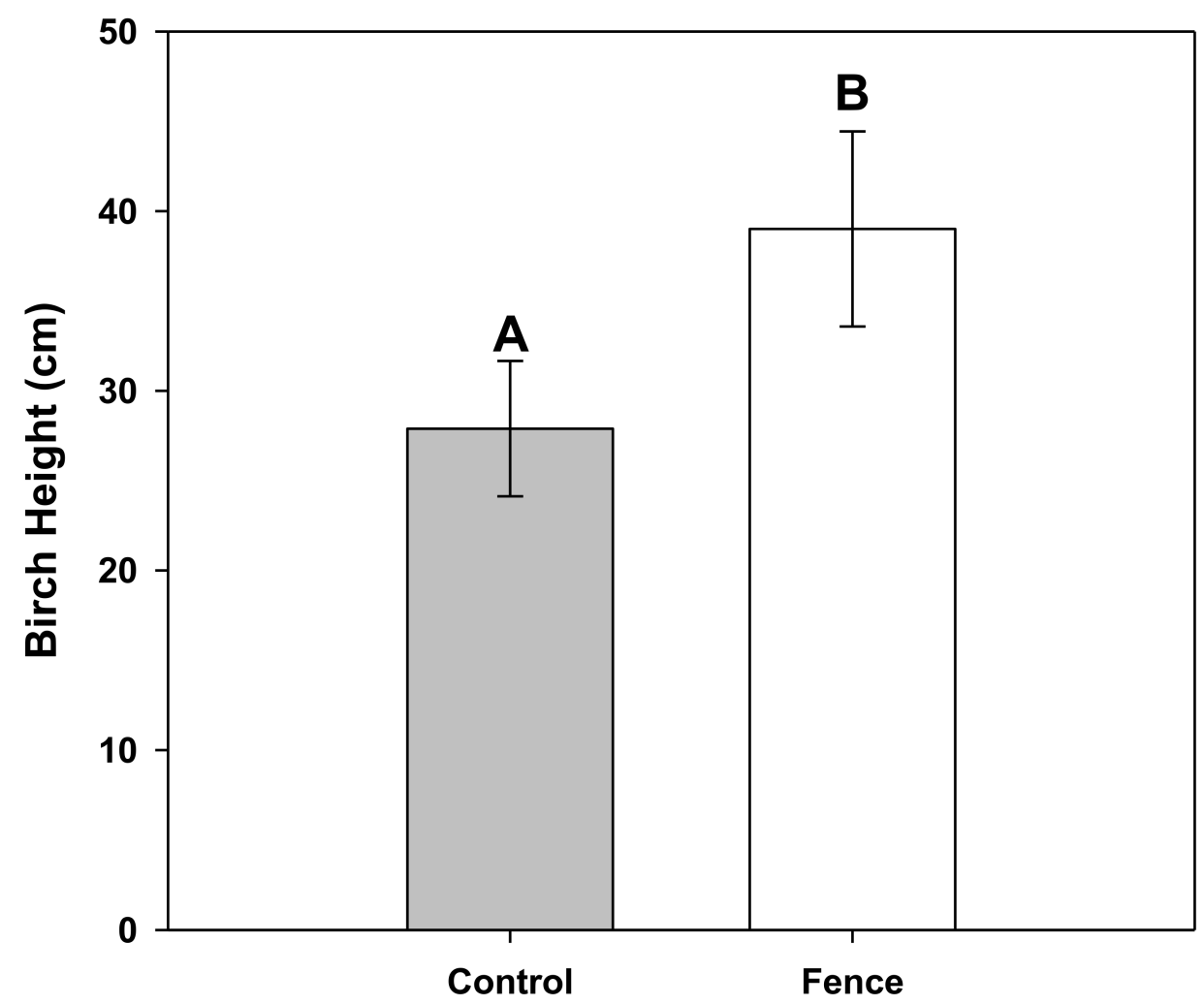

Figure 4. Effect of white-tailed deer browsing on birch height, averaged across all census periods. Letters denote a significant difference exists between browsing treatments. 


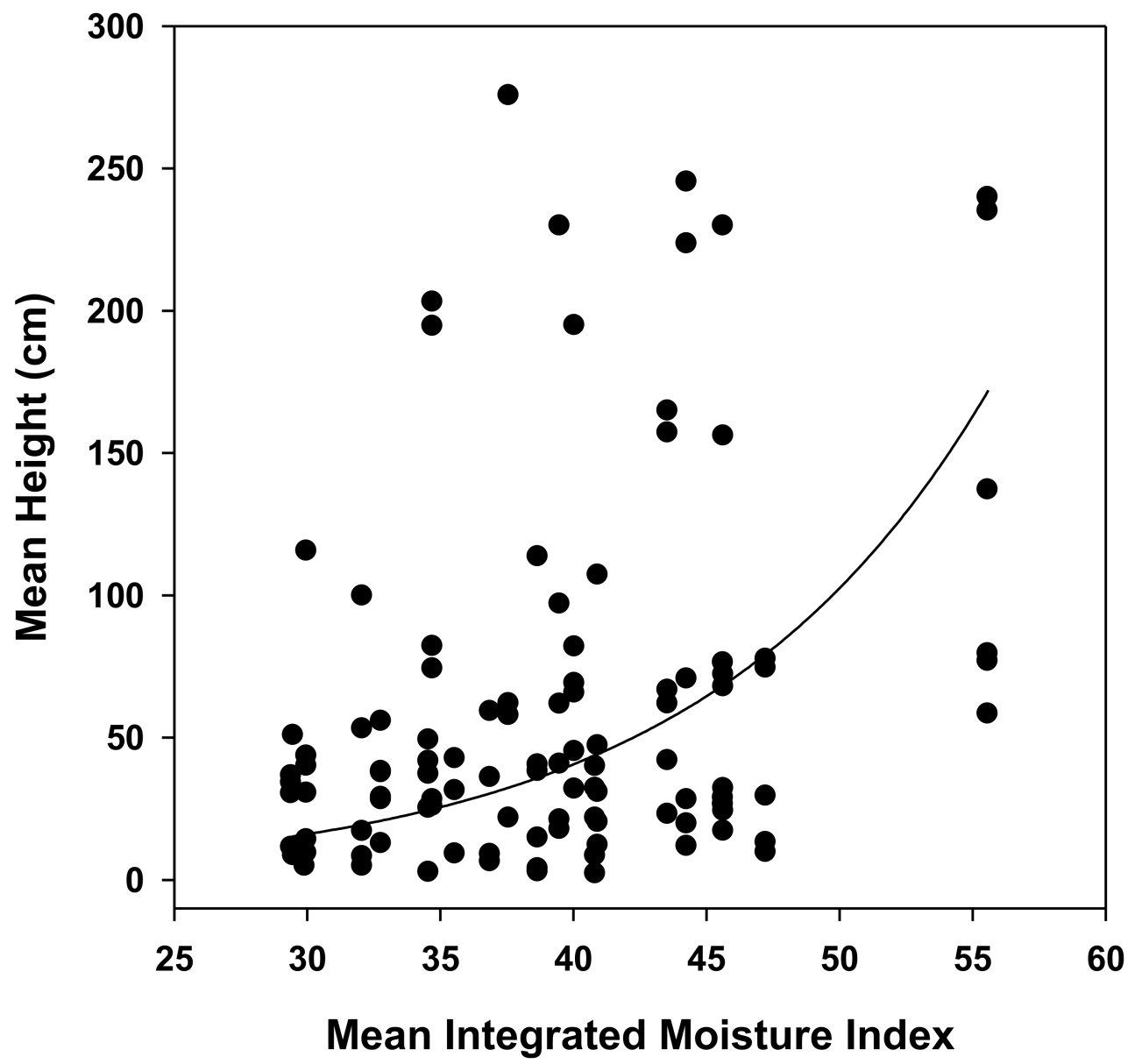

Figure 5. Logarithmic relationship between mean integrated moisture index (IMI; [32]) and birch seedling height $(\mathrm{cm})$. Plot shows data for all sites and all years.

Although combined seedling densities of desirable woody regeneration were, on average, nearly an order of magnitude greater than the birches in $2017\left(9.5 \pm 1.0\right.$ stems $/ \mathrm{m}^{2}$ versus $1.2 \pm 0.3$ stems $/ \mathrm{m}^{2}$, respectively), these were unaffected by either silvicultural sequence or browsing treatments (Appendix B). Similarly, desirable seedling heights were unaffected by treatments (Appendix B). The seedling heights of desirable species were uniformly short (Mean height in 2017: $29.3 \pm 3.2 \mathrm{~cm}$ ) among treatments and averaged less than half the height attained by birch stems.

\section{Discussion}

Our study demonstrates that a post-shelterwood herbicide application (S-H) initially reduced birch recruitment into stands. Mechanistically, post-shelterwood harvest applications coincide with the period during which birch recruitment is greatest, and therefore exert the strongest effect. Moreover, all sites in this study had sulfometuron methyl combined with glyphosate. Although glyphosate does not have residual activity, sulfometuron methyl does possess residual soil activity, which lasts for several months $[37,38]$ and thus may further limit birch recruitment. Although mist-blown herbicide effectiveness on interfering vegetation has been tested in pre- (e.g., [39]) and post-harvest contexts (e.g., [40]), to our knowledge, this is the first study to explicitly examine how variation in the timing of the harvest and herbicide sequence affects woody regeneration dynamics. In an experiment designed to test herbicide effects on plant diversity, Ristau and colleagues [41] had ten sites evenly split into either the H-S and S-H sequences. Although they found sequence did not affect overall plant diversity or composition, closer examination of the data suggests the $\mathrm{H}-\mathrm{S}$ sequence promotes birch (H-S: $5180 \pm 1986$ stems/ha versus S-H: $3070 \pm 934$ stems/ha, respectively; Ristau 
unpublished data). Our work also complements and expands findings of Kelty and Nyland [42] and Ray and colleagues [43], who found pre-shelterwood harvest herbicide applications promoted yellow birch (B. allegheniensis) in northern hardwood stands. Thus, our research supports management recommendations that control of competing woody vegetation may be most effective when the herbicide follows the harvest $[28,40,44,45]$.

Our results provide strong evidence that browsing reduces average birch seedling height development and potentially limits the increase in birch seedling density observed in the $\mathrm{H}-\mathrm{S}$ sequence. These findings concur with prior work that found browsing limits yellow and sweet birch [18,46-48]. Nevertheless, even in areas exposed to browsing birch seedlings were, on average, taller than the desirable regeneration by 2017. These results suggest birch seedlings may be either less preferred by deer, relatively resilient to browsing, or both. Indeed, Bressette and colleagues [17] rated both yellow and sweet birch as minimally sensitive to browsing, whereas some of the species we categorized as desirable regeneration (e.g., maples, northern red oak, and white ash (Fraxinus americana L.)) are often much more sensitive to browsing (see also [49]). This may explain why birches often dominate post-disturbance regeneration even under average deer densities much higher than those in our study areas $\left(11-18\right.$ deer $\left./ \mathrm{km}^{2} ;[18,19]\right)$. These findings demonstrate the challenge of sustaining diverse tree regeneration in Allegheny Plateau forests, as high browse impacts severely affect the regeneration of most tree species [18], and in present-day forests the fast-growing and relatively browse-insensitive birches dominate at moderate or even low (i.e., fences) browse impacts.

Our results also demonstrate that birch recruitment success is substantially enhanced by the presence of residual mature birch trees in the post-shelterwood canopy, specifically following the H-S sequence. The likely explanation is that these residual trees shed seeds that successfully germinated under the favorable seedbed conditions created by the harvest [50] and were not subsequently controlled by herbicide. These results are surprising given that a leading forest dynamics model (SORTIE; [51]) finds that birch is not strongly recruitment limited as a consequence of being a prolific seeder with extremely broad dispersal capabilities [14,52]. Our findings suggest that despite their broad dispersal ability, seed rain can still be positively influenced by the proximity of mature, seed-bearing trees (see [53]). Culling any mature birch trees from stands during the initial shelterwood cut will greatly limit, although not eliminate, birch recruitment.

Although birch grew taller in more productive sites, this relationship exhibited considerable variation. In our work, productivity was defined by a GIS-derived integrated moisture index [54]. This index is heavily weighted towards topographic and soil features of the landscape that govern moisture availability (i.e., direct solar radiation, slope position, curvature, and soil water-holding capacity). Thus, our findings suggest birch does have an affinity to sites with greater moisture but can nonetheless thrive across a wide variety of sites. Our results broadly concur with the existing literature that finds sweet and yellow birch thrive in cooler, moist sites at higher elevations with well-drained soils $[10,55]$. This versatility with regard to soil moisture relationships supports existing findings documenting the encroachment and survival of birch on drier sites, including ridgetops, even following droughts $[56,57]$.

Contrary to expectations, neither overstory relative density nor total nitrogen were identified as factors influencing birch establishment dynamics. The lack of a relative density effect is likely attributable to birch exhibiting a fairly labile response to variation in light conditions [20,58] coupled with post-shelterwood residual relative densities in our study that are intended to increase understory light to stimulate regeneration. Hence, in these sites, light is not limiting, particularly for taxa that perform well under a gamut of light levels. The lack of a nitrogen effect may be attributable to at least two causes. First, given that harvesting in the S-H stands occurred several years (Mean: 4.1 years) prior to the initial (2014) survey, whereas harvesting in the H-S stands occurred much closer to the sampling period (Mean: 1.4 years), this may mean that nitrogen is temporally confounded with treatment sequence, as overstory disturbances typically create an ephemeral pulse in soil ammonium and nitrate $[22,59]$. This explanation is supported by the fact that nitrogen concentrations in the H-S 
sequence stands were approximately $33 \%$ greater than those with the S-H sequence (20.6 versus $15.1 \mathrm{ppm}$ or $\mathrm{mg} / \mathrm{kg}$, respectively). Moreover, soil nitrogen may not be a key limiting resource for birch, particularly under higher light conditions [20,60]. While it is important to note that these caveats constrain our ability to test the importance of these variables across broader resource gradients, our goal was to assess their effects under real-world, operational management scenarios in this region. Hence, we caution readers not to extrapolate our findings to infer that, in general, canopy openness and nitrogen have no effect on birch establishment and growth.

\section{Conclusions}

Our results provide empirical confirmation that the shelterwood-herbicide sequence initially limits the establishment of birch seedlings relative to the herbicide-shelterwood sequence. This approach provides only a temporary reprieve, as within two years birch densities recovered to levels comparable to the herbicide-shelterwood. More importantly, given that in contemporary Allegheny and northern hardwood forests, birch grows faster than most of its competitors following overstory disturbance [4,46], birch rapidly overtop most other species. In fact, five growing seasons post-herbicide, birch seedlings were already over twice as tall as the desirable regeneration. Birch recruitment and growth were also influenced by propagule supply and deer browsing. Hence, shelterwood harvests are at greater risk of birch dominance when there are residual birch in the stands as possible seed sources and where browse pressure is low. Nevertheless, we caution that even in sites where birch seed source is lacking, where modest browse pressure limits birch growth, and when managers use a post-shelterwood herbicide (H-S) sequence to control birch, there is no guarantee that birch will not become established and grow to be the tallest competitors in the regenerating community. Thus, follow-up treatments such as broadcast herbicide or targeted cleanings (e.g., stem injection, basal spray) that remove undesirable, competing woody vegetation may be necessary to promote desirable regeneration [61].

Author Contributions: Conceptualization: A.A.R., C.C.P., and S.L.S.; Formal analysis: J.S.S. and A.A.R.; Funding acquisition: A.A.R. and S.L.S.; Investigation: A.A.R., C.C.P., and S.L.S.; Methodology: A.A.R., C.C.P., J.S.S., and S.L.S.; Supervision: A.A.R.; Writing—original draft: A.A.R.; Writing-review and editing: A.A.R., C.C.P., J.S.S., and S.L.S.

Funding: This work was supported by the USDA-AFRI Award \#12-IA-11242302-093, the USDA-FS Northern Research Station.

Acknowledgments: We thank the Allegheny National Forest, the Pennsylvania Bureau of Forestry, Bradford Water Authority, Forest Investment Associates, Generations Forestry, Hancock Forest Management, and Landvest and Kane Hardwoods for field sites. We are indebted to Charles Vandever for leading summer field crews and Matthew Peters for calculation of IMI values. Melissa Thomas-Van Gundy and Tara Keyser provided valuable editorial suggestions.

Conflicts of Interest: The authors declare no conflict of interest. 


\section{Appendix A}

Table A1. Site characteristics of the 22 experimental sites. Sequence denotes whether sites received a herbicide preceding the shelterwood harvest (H-S) or if the herbicide was applied post-harvest $(\mathrm{S}-\mathrm{H})$. Browsing refers to the 0.42 -ha fenced and unfenced areas. IMI is the integrated moisture index, a metric of soil moisture availability and productivity based on GIS-derived metrics [32]. Basal area is in $\mathrm{m}^{2}$ per hectare. Relative density is a measure of overstory crowding [33]. Birch seed source (Absent/Present) denotes whether there were any residual canopy birch (B. allegheniensis or B. lenta) in the canopy post-shelterwood harvest. We also present elevation (meters), slope (degrees), and aspect for each site.

\begin{tabular}{|c|c|c|c|c|c|c|c|c|c|c|c|}
\hline Site & Sequence & Browsing & IMI & Basal Area & Relative Density & Overstory Birch & Herbicide Year & Harvest Date & Elevation & Slope & Aspect \\
\hline Balanton & HS & $\begin{array}{c}\text { Exclosure } \\
\text { Control }\end{array}$ & 29.4 & $\begin{array}{l}17.9 \\
15.7\end{array}$ & $\begin{array}{l}42 \\
37\end{array}$ & $\begin{array}{l}\text { Absent } \\
\text { Absent }\end{array}$ & 2009 & 2012 & 640.9 & 5.2 & south \\
\hline Bump Run & HS & $\begin{array}{c}\text { Exclosure } \\
\text { Control }\end{array}$ & 36.9 & $\begin{array}{l}27.2 \\
18.0\end{array}$ & $\begin{array}{l}87 \\
63\end{array}$ & $\begin{array}{l}\text { Absent } \\
\text { Present }\end{array}$ & 2012 & 2013 & 548.1 & 15.5 & west \\
\hline BWAC-C9 & HS & $\begin{array}{c}\text { Control } \\
\text { Exclosure }\end{array}$ & 34.6 & $\begin{array}{l}15.6 \\
12.2\end{array}$ & $\begin{array}{l}28 \\
34\end{array}$ & $\begin{array}{l}\text { Absent } \\
\text { Absent }\end{array}$ & 2011 & 2012 & 700.2 & 3.3 & west \\
\hline Cash Crop & HS & $\begin{array}{c}\text { Control } \\
\text { Exclosure }\end{array}$ & 45.6 & $\begin{array}{c}9.6 \\
20.5\end{array}$ & $\begin{array}{l}41 \\
30\end{array}$ & $\begin{array}{l}\text { Absent } \\
\text { Absent }\end{array}$ & 2009 & 2013 & 640.2 & 6.7 & northeast \\
\hline Close Call & HS & $\begin{array}{c}\text { Exclosure } \\
\text { Control }\end{array}$ & 34.7 & $\begin{array}{l}14.7 \\
22.3\end{array}$ & $\begin{array}{l}35 \\
52\end{array}$ & $\begin{array}{l}\text { Absent } \\
\text { Present }\end{array}$ & 2010 & 2013 & 610.5 & 3.4 & south \\
\hline Potter11 & HS & $\begin{array}{l}\text { Control } \\
\text { Exclosure }\end{array}$ & 44.3 & $\begin{array}{l}19.3 \\
21.4\end{array}$ & $\begin{array}{l}51 \\
52\end{array}$ & $\begin{array}{l}\text { Absent } \\
\text { Absent }\end{array}$ & 2012 & 2013 & 641.0 & 2.2 & north \\
\hline Rush & HS & $\begin{array}{c}\text { Exclosure } \\
\text { Control }\end{array}$ & 35.6 & $\begin{array}{l}20.2 \\
18.9\end{array}$ & $\begin{array}{l}64 \\
42\end{array}$ & $\begin{array}{l}\text { Absent } \\
\text { Absent }\end{array}$ & 2010 & 2014 & 667.6 & 18.2 & southeast \\
\hline ScreamingEagle & HS & $\begin{array}{c}\text { Control } \\
\text { Exclosure }\end{array}$ & 37.6 & $\begin{array}{l}18.4 \\
12.8\end{array}$ & $\begin{array}{l}31 \\
48\end{array}$ & $\begin{array}{l}\text { Absent } \\
\text { Absent }\end{array}$ & 2009 & 2012 & 670.9 & 2.6 & north \\
\hline Second Look & HS & $\begin{array}{c}\text { Exclosure } \\
\text { Control }\end{array}$ & 40.9 & $\begin{array}{l}17.1 \\
20.3\end{array}$ & $\begin{array}{l}35 \\
57\end{array}$ & $\begin{array}{l}\text { Absent } \\
\text { Present }\end{array}$ & 2012 & 2013 & 532.6 & 4.1 & north \\
\hline ShakenBake & HS & $\begin{array}{l}\text { Control } \\
\text { Exclosure }\end{array}$ & 43.6 & $\begin{array}{l}24.1 \\
19.9\end{array}$ & $\begin{array}{l}66 \\
69\end{array}$ & $\begin{array}{l}\text { Present } \\
\text { Present }\end{array}$ & 2009 & 2012 & 564.1 & 25.9 & southeast \\
\hline Sorry About That & HS & $\begin{array}{c}\text { Exclosure } \\
\text { Control }\end{array}$ & 45.7 & $\begin{array}{l}15.6 \\
13.3\end{array}$ & $\begin{array}{l}37 \\
30\end{array}$ & $\begin{array}{l}\text { Absent } \\
\text { Absent }\end{array}$ & 2010 & 2012 & 608.3 & 26.5 & northwest \\
\hline Treed Bear & HS & $\begin{array}{c}\text { Control } \\
\text { Exclosure }\end{array}$ & 55.6 & $\begin{array}{l}21.0 \\
22.9\end{array}$ & $\begin{array}{l}39 \\
39\end{array}$ & $\begin{array}{l}\text { Absent } \\
\text { Absent }\end{array}$ & 2009 & 2012 & 531.6 & 14.2 & north \\
\hline BloodyRun & SH & $\begin{array}{c}\text { Exclosure } \\
\text { Control }\end{array}$ & 29.5 & $\begin{array}{l}30.2 \\
20.0\end{array}$ & $\begin{array}{l}64 \\
48\end{array}$ & $\begin{array}{l}\text { Absent } \\
\text { Present }\end{array}$ & 2012 & 2009 & 569.2 & 4.1 & south \\
\hline Bradford 40 & SH & $\begin{array}{l}\text { Control } \\
\text { Exclosure }\end{array}$ & 38.7 & $\begin{array}{l}10.6 \\
19.7\end{array}$ & $\begin{array}{l}44 \\
28\end{array}$ & $\begin{array}{l}\text { Absent } \\
\text { Absent }\end{array}$ & 2012 & 2011 & 669.9 & 0.2 & north \\
\hline BuntsRun & SH & $\begin{array}{c}\text { Exclosure } \\
\text { Control }\end{array}$ & 29.9 & $\begin{array}{l}16.3 \\
23.2\end{array}$ & 34 & $\begin{array}{l}\text { Absent } \\
\text { Absent }\end{array}$ & 2012 & 2008 & 544.6 & 2.8 & south \\
\hline Compressor & SH & $\begin{array}{l}\text { Control } \\
\text { Exclosure }\end{array}$ & 32.1 & $\begin{array}{l}21.6 \\
17.0\end{array}$ & $\begin{array}{l}46 \\
62\end{array}$ & $\begin{array}{l}\text { Present } \\
\text { Absent }\end{array}$ & 2012 & 2012 & 538.6 & 29.8 & south \\
\hline
\end{tabular}


Table A1. Cont.

\begin{tabular}{|c|c|c|c|c|c|c|c|c|c|c|c|}
\hline Site & Sequence & Browsing & IMI & Basal Area & Relative Density & Overstory Birch & Herbicide Year & Harvest Date & Elevation & Slope & Aspect \\
\hline First Hunt & $\mathrm{SH}$ & $\begin{array}{c}\text { Exclosure } \\
\text { Control }\end{array}$ & 30.0 & $\begin{array}{l}28.1 \\
24.1\end{array}$ & $\begin{array}{l}53 \\
48\end{array}$ & $\begin{array}{l}\text { Absent } \\
\text { Absent }\end{array}$ & 2012 & 2011 & 513.7 & 2.9 & southeast \\
\hline Irvine Run & $\mathrm{SH}$ & $\begin{array}{l}\text { Exclosure } \\
\text { Control }\end{array}$ & 40.1 & $\begin{array}{l}24.1 \\
14.9 \\
14.6\end{array}$ & $\begin{array}{l}47 \\
27\end{array}$ & $\begin{array}{l}\text { Absent } \\
\text { Absent } \\
\text { Absent }\end{array}$ & 2012 & 2010 & 513.9 & 1.6 & east \\
\hline McKean 37 & $\mathrm{SH}$ & $\begin{array}{l}\text { Control } \\
\text { Exclosure }\end{array}$ & 47.2 & $\begin{array}{l}18.5 \\
16.9\end{array}$ & $\begin{array}{l}49 \\
46\end{array}$ & $\begin{array}{l}\text { Present } \\
\text { Absent }\end{array}$ & 2012 & 2010 & 676.7 & 7.8 & east \\
\hline Potter6 & $\mathrm{SH}$ & $\begin{array}{l}\text { Control } \\
\text { Exclosure }\end{array}$ & 40.8 & $\begin{array}{l}15.3 \\
17.2\end{array}$ & $\begin{array}{l}36 \\
39\end{array}$ & $\begin{array}{l}\text { Absent } \\
\text { Present }\end{array}$ & 2012 & 2012 & 687.8 & 4.8 & northeast \\
\hline Regen 134 & $\mathrm{SH}$ & $\begin{array}{l}\text { Exclosure } \\
\text { Control }\end{array}$ & 32.8 & $\begin{array}{l}19.3 \\
31.8\end{array}$ & $\begin{array}{l}38 \\
61\end{array}$ & $\begin{array}{l}\text { Present } \\
\text { Present }\end{array}$ & 2012 & 2005 & 555.3 & 3.2 & southeast \\
\hline Spring Creek & $\mathrm{SH}$ & $\begin{array}{l}\text { Exclosure } \\
\text { Control }\end{array}$ & 39.5 & $\begin{array}{l}22.8 \\
28.5\end{array}$ & $\begin{array}{l}44 \\
57\end{array}$ & $\begin{array}{l}\text { Absent } \\
\text { Absent }\end{array}$ & 2012 & 2011 & 544.4 & 3.6 & southeast \\
\hline
\end{tabular}




\section{Appendix B}

Table A2. Generalized linear mixed model results on (A) seedling densities and (B) seedling heights (cm) for all desirable species. Desirable species include Acer rubrum L., A. saccharum Marshall, Fraxinus americana L., Liriodendron tulipifera L., Magnolia acuminata L., Prunus serotina Ehrh., and Quercus rubra L.

\begin{tabular}{ccc}
\hline \multicolumn{3}{c}{ (A) All Desirable Seedling Density 2017} \\
\hline Effect & $\boldsymbol{F}$-Value & $\boldsymbol{p}$-Value \\
\hline Sequence & $F_{1,20.0}=0.25$ & 0.624 \\
Exclosure & $F_{1,20.0}=2.34$ & 0.142 \\
Exclosure $\times$ Sequence & $F_{1,20.0}=0.07$ & 0.798 \\
\hline (B) All Desirable Seedling Height 2017 \\
\hline Effect & $\boldsymbol{F}$-Value & $\boldsymbol{p}$-Value \\
\hline Sequence & $F_{1,20.0}=0.00$ & 0.984 \\
Exclosure & $F_{1,20.0}=1.75$ & 0.201 \\
Exclosure $\times$ Sequence & $F_{1,20.0}=0.00$ & 0.993 \\
\hline
\end{tabular}

\section{References}

1. Albright, T.A.; McWilliams, W.H.; Widmann, R.H.; Butler, B.J.; Crocker, S.J.; Kurtz, C.M.; Lehman, S.; Lister, T.W.; Miles, P.D.; Morin, R.S.; et al. Pennsylvania Forests 2014. Resource Bulletin. NRS-111; USDA Forest Service, Northern Research Station: Newtown Square, PA, USA, 2017.

2. Widmann, R.H.; Crawford, S.; Kurtz, C.M.; Nelson, M.D.; Miles, P.D.; Morin, R.S.; Rienmann, R. New York Forests, 2012. Resource Bulletin NRS-98; USDA Forest Service, Northern Research Station: Newtown Square, PA, USA, 2015.

3. Kizlinski, M.L.; Orwig, D.A.; Cobb, R.C.; Foster, D.R. Direct and indirect ecosystem consequences of an invasive pest on forests dominated by eastern hemlock. J. Biogeogr. 2002, 29, 1489-1503. [CrossRef]

4. Royo, A.A.; Peterson, C.J.; Stanovick, J.S.; Carson, W.P. Evaluating the ecological impacts of salvage logging: Can natural and anthropogenic disturbances promote coexistence? Ecology 2016, 97, 1566-1582. [CrossRef]

5. Ward, J.S.; Stephens, G.R. Influence of crown class on survival and development of Betula lenta in Connecticut, U.S.A. Can. J. For. Res. 1996, 26, 277-288. [CrossRef]

6. Fei, S.; Gould, P.J.; Steiner, K.C.; Finley, J.C.; McDill, M.E. Forest regeneration composition and development in upland, mixed-oak forests. Tree Physiol. 2005, 25, 1495-1500. [CrossRef]

7. Plotkin, A.B.; Foster, D.; Carlson, J.; Magill, A. Survivors, not invaders, control forest development following simulated hurricane. Ecology 2013, 94, 414-423. [CrossRef] [PubMed]

8. Morin, R.S.; Cook, G.W.; Barnett, C.J.; Butler, B.J.; Crocker, S.J.; Hatfield, M.A.; Kurtz, C.M.; Lister, T.W.; Luppold, W.G.; McWilliams, W.H.; et al. West Virginia Forests 2013. Resource Bulletin NRS-105; USDA Forest Service, Northern Research Station: Newtown Square, PA, USA, 2016.

9. Abrams, M.D. The red maple paradox: What explains the widespread expansion of red maple in eastern forests? Bioscience 1998, 48, 355-364. [CrossRef]

10. Burns, R.M.; Honkala, B.H. (Eds.) Silvics of North America; United States Department of Agriculture, Forest Service: Washington, DC, USA, 1990.

11. Baker, F.S. A revised tolerance table. J. For. 1949, 47, 179-181.

12. de la Cretaz, A.L.; Kelty, M.J. Establishment and control of hay-scented fern: A native invasive species. Biol. Invasions 1999, 1, 223-236. [CrossRef]

13. Horsley, S.B.; Marquis, D.A. Interference by weeds and deer with Allegheny (Pennsylvania, USA) hardwood reproduction. Can. J. For. Res. 1983, 13, 61-69. [CrossRef]

14. Matlack, G.R. Secondary dispersal of seed across snow in Betula lenta, a gap-colonizing tree species. J. Ecol. 1989, 77, 853-869. [CrossRef]

15. Godman, R.M.; Krefting, L.W. Factors important to yellow birch establishment in Upper Michigan. Ecology 1960, 41, 18-28. [CrossRef] 
16. Marquis, D.A. Regeneration of Birch and Associated Hardwoods after Patch Cutting. Research Paper NE-32; USDA Forest Service, Northeastern Forest Experiment Station: Upper Darby, PA, USA, 1964.

17. Bressette, J.W.; Beck, H.; Beauchamp, V.B. Beyond the browse line: Complex cascade effects mediated by white-tailed deer. Oikos 2012, 121, 1749-1760. [CrossRef]

18. Horsley, S.B.; Stout, S.L.; deCalesta, D.S. White-tailed deer impact on the vegetation dynamics of a northern hardwood forest. Ecol. Appl. 2003, 13, 98-118. [CrossRef]

19. Nuttle, T.; Royo, A.A.; Adams, M.B.; Carson, W.P. Historic disturbance regimes promote tree diversity only under low browsing regimes in eastern deciduous forest. Ecol. Monogr. 2013, 83, 3-17. [CrossRef]

20. Fownes, J.H.; Harrington, R.A. Seedling response to gaps: Separating effects of light and nitrogen. For. Ecol. Manag. 2004, 203, 297-310. [CrossRef]

21. Crabtree, R.C.; Bazzaz, F.A. Seedling response of four birch species to simulated nitrogen deposition: Ammonium vs. nitrate. Ecol. Appl. 1993, 3, 315-321. [CrossRef]

22. Falxa-Raymond, N.; Patterson, A.E.; Schuster, W.S.F.; Griffin, K.L. Oak loss increases foliar nitrogen, $\delta 15 \mathrm{~N}$ and growth rates of Betula lenta in a northern temperate deciduous forest. Tree Physiol. 2012, 32, 1092-1101. [CrossRef]

23. Mou, P.; Fahey, T.J.; Hughes, J.W. Effects of soil disturbance on vegetation recovery and nutrient accumulation following whole-tree harvest of a northern hardwood ecosystem. J. Appl. Ecol. 1993, 30, 661-675. [CrossRef]

24. Marquis, D.A.; Ernst, R.L.; Stout, S.L. (Eds.) Prescribing Silvicultural Treatments in Hardwood Stands of the Alleghenies (Revised), Gen. Tech. Rep. NE-96; USDA Forest Service Northeastern Research Station: Radnor, PA, USA, 1992; p. 101.

25. Hannah, P.R. Regeneration of northern hardwoods in the northeast with the shelterwood method. North J. Appl. For. 1991, 8, 99-104.

26. Horsley, S.B. Regeneration success and plant species diversity of Allegheny hardwood stands after Roundup application and shelterwood cutting. N. J. Appl. For. 1994, 11, 109-116.

27. Nyland, R.D. (Ed.) Silviculture-Concepts and Applications, 2nd ed.; McGraw-Hill: New York, NY, USA, 2002; p. 682.

28. Ristau, T.E.; Horsley, S.B. When is pin cherry (Prunus pensylvanica L.) a problem in Allegheny hardwoods? North J. Appl. For. 2006, 23, 204-210.

29. Bailey, S.W.; Horsley, S.B.; Long, R.P. Thirty years of change in forest soils of the Allegheny Plateau, Pennsylvania. Soil Sci. Soc. Am. J. 2005, 69, 681-690. [CrossRef]

30. Redding, J. History of deer population trends and forest cutting on the Allegheny National Forest. In Proceedings of the 10th Central Hardwood Forest Conference; Gottschalk, K.W., Fosbroke, S.L.C., Eds.; Gen. Tech. Rep. NE-197; USDA Forest Service: Morgantown, WV, USA, 1995; pp. 214-224.

31. Horsley, S.B.; McCormick, L.H.; Groninger, J.W. Effects of timing of Oust application on survival of hardwood seedlings. North. Jour. Appl. For. 1992, 9, 22-27.

32. Iverson, L.R.; Dale, M.E.; Scott, C.T.; Prasad, A. A GIS-derived integrated moisture index to predict forest composition and productivity of Ohio forests (USA). Landsc. Ecol. 1997, 12, 331-348. [CrossRef]

33. Stout, S.L.; Nyland, R.D. Role of species composition in relative density measurement in Allegheny hardwoods. Can. J. For. Res. 1986, 16, 574-579. [CrossRef]

34. SAS Institute Inc. SAS System for Windows, 9.4; SAS Institute Inc.: Cary, NC, USA, 2013.

35. Littell, R.C.; Milliken, G.A.; Stroup, W.W.; Wolfinger, R.D.; Schabenberger, O. SAS for Mixed Models, 2nd ed.; SAS Institute, Inc.: Cary, NC, USA, 2006.

36. Brown, M.B.; Forsythe, A.B. Robust tests for the equality of variances. J. Am. Stat. Assoc. 1974, 69, $364-367$. [CrossRef]

37. Anderson, J.J.; Dulka, J.J. Environmental fate of sulfometuron methyl in aerobic soils. J. Agric. Food Chem. 1985, 33, 596-602. [CrossRef]

38. Harvey, J.J.; Dulka, J.J.; Anderson, J.J. Properties of sulfometuron methyl affecting its environmental fate: Aqueous hydrolysis and photolysis, mobility and adsorption on soils, and bioaccumulation potential. J. Agric. Food Chem. 1985, 33, 590-596. [CrossRef]

39. Ostrofsky, W.D.; McCormack, J.M.L. Silvicultural management of beech and the beech bark disease. N. J. Appl. For. 1986, 3, 89-91. [CrossRef]

40. Bose, A.K.; Wagner, R.G.; Roth, B.E.; Weiskittel, A.R. Influence of browsing damage and overstory cover on regeneration of American beech and sugar maple nine years following understory herbicide release in central Maine. New For. 2018, 49, 67-85. [CrossRef] 
41. Ristau, T.E.; Stoleson, S.H.; Horsley, S.B.; deCalesta, D.S. Ten-year response of the herbaceous layer to an operational herbicide-shelterwood treatment in a northern hardwood forest. For. Ecol. Manag. 2011, 262, 970-979. [CrossRef]

42. Kelty, M.J.; Nyland, R.D. Regenerating Adirondack northern hardwoods by shelterwood cutting and control of deer density. J. For. 1981, 79, 22-26.

43. Ray, D.G.; Nyland, R.D.; Yanai, R.D. Patterns of early cohort development following shelterwood cutting in three Adirondack northern hardwood stands. For. Ecol. Manag. 1999, 119, 1-11. [CrossRef]

44. Nelson, A.S.; Wagner, R.G. Improving the composition of beech-dominated northern hardwood understories in northern Maine. N. J. Appl. For. 2011, 28, 186-193. [CrossRef]

45. Bell, F.W.; Newmaster, S.G. The effects of silvicultural disturbances on the diversity of seed-producing plants in the boreal mixedwood forest. Can. J. For. Res. 2002, 32, 1180-1191. [CrossRef]

46. Krueger, L.M.; Peterson, C.J.; Royo, A.; Carson, W.P. Evaluating relationships among tree growth rate, shade tolerance, and browse tolerance following disturbance in an eastern deciduous forest. Can. J. For. Res. 2009, 39, 2460-2469. [CrossRef]

47. Kern, C.C.; Reich, P.B.; Montgomery, R.A.; Strong, T.F. Do deer and shrubs override canopy gap size effects on growth and survival of yellow birch, northern red oak, eastern white pine, and eastern hemlock seedlings? For. Ecol. Manag. 2012, 267, 134-143. [CrossRef]

48. Kain, M.; Battaglia, L.; Royo, A.; Carson, W.P. Over-browsing in Pennsylvania creates a depauperate forest dominated by an understory tree: Results from a 60-year-old deer exclosure. J. Torrey Bot. Soc. 2011, 138, 322-326. [CrossRef]

49. Healy, W.M. Forage preferences of tame deer in a Northwest Pennsylvania clear-cutting. J. Wildl. Manag. 1971, 35, 717-723. [CrossRef]

50. Tubbs, C.H. The Influence of Light, Moisture, and Seedbed on Yellow Birch Regeneration; Research Paper NC-27; US Dept. of Agriculture, Forest Service, North Central Forest Experiment Station: St. Paul, MN, USA, 1969.

51. Ribbens, E.; Silander, J.A.; Pacala, S.W. Seedling recruitment in forests: Calibrating models to predict patterns of tree seedling dispersion. Ecology 1994, 75, 1794-1806. [CrossRef]

52. Caspersen, J.P.; Saprunoff, M. Seedling recruitment in a northern temperate forest: The relative importance of supply and establishment limitation. Can. J. For. Res. 2005, 35, 978-989. [CrossRef]

53. Houle, G. Seed dispersal and seedling recruitment of Betula alleghaniensis: Spatial inconsistency in time. Ecology 1998, 79, 807-818. [CrossRef]

54. Iverson, L.R.; Prasad, A.M. A.M. A GIS-derived integrated moisture index. In Characteristics of Mixed Oak Forest Ecosystems in Southern Ohio Prior to the Reintroduction of Fire; Gen. Tech. Rep. NE-299; U.S. Department of Agriculture, Forest Service: Newtown Square, PA, USA, 2003; pp. $29-41$.

55. Prasad, A.M.; Iverson, L.R.; Peters, M.P.; Matthews, S.N. Climate Change Tree Atlas. Available online: http:/ / www.nrs.fs.fed.us/atlas (accessed on 9 September 2018).

56. Elliott, K.J.; Swank, W.T. Impacts of drought on tree mortality and growth in a mixed hardwood forest. J. Veg. Sci. 1994, 5, 229-236. [CrossRef]

57. Nowacki, G.J.; Abrams, M.D. Community and edaphic analysis of mixed oak forests in the ridge and valley province of central Pennsylvania. In Proceedings of the 8th Central Hardwood Forest Conference, Radnor, PA, USA, 4-6 March 1991; Gen. Tech. Rep NE-148, pp. 247-260.

58. Beaudet, M.; Messier, C. Growth and morphological responses of yellow birch, sugar maple, and beech seedlings growing under a natural light gradient. Can. J. For. Res. 1998, 28, 1007-1015. [CrossRef]

59. Holmes, W.E.; Zak, D.R. Soil microbial control of nitrogen loss following clear-cut harvest in northern hardwood ecosystems. Ecol. Appl. 1999, 9, 202-215. [CrossRef]

60. Catovsky, S.; Bazzaz, F.A. The role of resource interactions and seedling regeneration in maintaining a positive feedback in hemlock stands. J. Ecol. 2000, 88, 100-112. [CrossRef]

61. Ristau, T.E.; Horsley, S.B. Pin cherry effects on Allegheny hardwood stand development. Can. J. For. Res. 1999, 29, 73-84. [CrossRef]

(C) 2019 by the authors. Licensee MDPI, Basel, Switzerland. This article is an open access article distributed under the terms and conditions of the Creative Commons Attribution (CC BY) license (http:/ / creativecommons.org/licenses/by/4.0/). 